DOI 10.37882/2223-2982.2021.01.32

\title{
ИННОВАЦИОННЫЕ ПРИЕМЫ ОБУЧЕНИЯ КИТАЙСКИХ СТУДЕНТОВ РУССКОЙ ГРАММАТИКЕ (УРОВЕНЬ А2)
}

\section{INNOVATIVE TECHNIQUES OF TEACHING CHINESE STUDENTS TO RUSSIAN GRAMMAR (LEVEL A2)}

Sun $Y u$

Summary: This article deals with the problem of optimization the process of Teaching Russian grammar to Chinese students (Level A2). The choice of innovative techniques is substantiated that take into account the cognitive and psychological, national and cultural characteristics of Chinese students. It is concluded that the developed innovative techniques meets the communicative needs of Chinese students as much possible, contributes to the formation of linguistic, speech and sociocultural competences in Russian.

Keywords: Grammar exercises, innovative methods, Russian as a foreign language (RFL), Chinese students, Level A2.
$\mathrm{B}$ последние годы в методике преподавания иностранных языков (в том числе русского языка как иностранного) наблюдается стремление найти и внедрить наиболее оптимальные приемы обучения. Вслед за Е.И. Пассовым мы рассматриваем прием как основную единицу учебного воздействия, обеспечивающую решение конкретных учебных задач для достижения поставленной цели [4. С. 73].

Методисты выделяют следующие инновационные приемы:

- инновационные технологии (информационные образовательные, информационно-коммуникативные, технология дистанционного обучения, Интернет-ресурсы и др.);

- интерактивные (дискуссия, работа в парах, в группах);

- схемно-графические (схема-опора, кластер, диаграмма);

- изобразительно-наглядные (рисунки-кроки, визитная карточка, презентация);

- творческие (учебный видеоклип, экскурсия, проект);

- игровые;

- познавательные (мнемотехника, "мозговая атака", дебаты):

- личностно-ориентированные (портфолио);

- коллективные (Cooperative Learning, взаимопроверка) $[1 ; 2 ; 3 ; 5 ; 7]$.

С нашей точки зрения, инновационные приемы, ис-
Суньюй

Аспирант, Санкт-Петербургский государственный университет st059610@student.spbu.ru

Аннотация: В данной работе решается проблема оптимизации процесса обучения китайских студентов русской грамматике (уровень А2). Обоснован выбор приемов, которые учитывают когнитивно-психологические и национально-культурные особенности носителей китайского языка. Делается вывод о том, что разработанный комплекс упражнений с использованием инновационных приемов, максимально отвечает коммуникативным потребностям китайских учащихся, способствует формированию языковой, речевой и социокультурной компетенций на русском языке.

Ключевые слова: грамматические упражнения, инновационные приемы, русский язык как иностранный (РКИ), китайские учащиеся, Базовый уровень (А2).

пользуемые в национально ориентированном практическом курсе иностранного языка, должны быть представлены системно, соответствовать целям и задачам обучения и активизировать взаимодействие "преподаватель $\leftrightarrow$ студент" и “студент $\leftrightarrow$ студент".

Опыт преподавания РКИ показывает, что работа с китайской аудиторией в рамках традиционных подходов к грамматике не приносит желаемых результатов. Однако до сих пор не разработана методика формирования грамматических навыков у китайских студентов с помощью приемов, которые учитывают когнитивно-психологические и этнокультурные особенности данного контингента учащихся [6]. Это осложняет процесс усвоения грамматических явлений русского языка в разных видах речевой деятельности и может приводить к коммуникативным неудачам.

Выступая в качестве средства обучения грамматике, комплекс упражнений и реализуемые в нем приемы должны обеспечивать не только формирование грамматической компетенции, но и устойчивый интерес, мотивацию к изучению русской грамматики, особенно на начальном этапе.

Приведем некоторые примеры грамматических упражнений с использованием инновационных приемов (урок «Что нужно взять в путешествие?» Грамматическая тема: Несогласованные определения. Способы выражения предиката: нужно/надо/можно/нельзя + инфинитив). 
1. Упражнения, основанные на ассоциациях и кодировании информации образами, которые представлены в зрительном или звуковом виде (мнемонический прием «Мнемодорожки»).

- Смотрите, запоминайте, повторяйте.

а) Посмотрите фотографии. Слушайте подписи и читайте. (1 мин.)

б) Посмотрите фотографии и подписи ещё раз (40 сек.) и запомните их.

в) Посмотрите фотографии, назовите предметы.

г) Посмотрите фотографии и подписи ещё раз (30 сек.), запомните словосочетания и повторите их в любой последовательности.

д) Посмотрите подписи ещё раз (30 сек.), повторите их в той же последовательности.

Восстановите словосочетания и нарисуйте соответствующие предметы.

2. В грамматических упражнениях можно использовать разработанный нами прием «Шеринг»: студенты делятся друг с другом фотографиями и видеороликами, хранящимися в их мобильных телефонах.

- Обменяйтесь со студентами Вашей группы фотографиями из мобильного телефона. Постройте диалоги, используя вопросы КТО ЭТО? или ЧТО ЭТО? (3 мин.)

3. Упражнения с использованием игровых приемов: «Рулетка» (в командах), «Монета» (в парах), «Карты» (индивидуальная работа, в парах, в командах) и др.
- Игра «Карты». Описание игры: На каждой карте рисунок (предмет) и перевод глагола на китайский язык (для использования при объяснении причины). Карты перевернуты. Студент берет одну карту, смотрит, что на ней изображено, и говорит: «Мне (не) нужно/надо ..., потому что ...»

4. При обучении грамматике русского языка можно развивать логическое мышление учащихся. В результате максимально активизируется деятельность левого полушария, что чрезвычайно важно для носителей китайского языка. Это возможно при использовании, например, приема «Калькулятор».

- Прочитайте задачу и решите ее. Назовите время глаголов. Составьте свои задачи.

Во сколько закончится экскурсия, если она началась в 14.15 и длится 1,5 часа?

Таким образом, предлагаемые нами упражнения для обучения китайских студентов русской грамматике отличаются от традиционных языковых упражнений, поскольку используемые инновационные приемы характеризуются коммуникативной направленностью, системностью, функциональностью. Инновационные приемы дают возможность преодолеть межъязыковую интерференцию, снизить или снять психологический барьер, повысить уровень мотивации, инициативности и активности учащихся, что способствует эффективному формированию коммуникативной компетенции.

\section{ЛИТЕРАТУРА}

1. Константинова Л.А., Тихонова 0.Ю. Квантование как один из основных способов подачи грамматических знаний при обучении РКИ // Известия ТулГУ. Гуманитарные науки. 2012. №1-2. С. 297-305.

2. Наймушина Т.А. Электронные помощники на уроках РКИ // Динамика языковых и культурных процессов в современной России. Вып. 6. Материалы VI Конгресса РОПРЯЛ (17-20 октября 2018 года, Уфа (Республика Башкортостан). СПб.: РОПРЯЛ, 2018. СD. С. 1606-1611.

3. Новикова А.К. К вопросу о видеоматериалах на уроке РКИ в китайской аудитории // Вестник РУДН. Серия: Вопросы образования: языки и специальность. 2013. № 4. С. 159-164.

4. Пассов Е.И. Методика как наука будущего. Краткая версия новой концепции. СПб.: Златоуст, 2015. 172 с.

5. Подласый И.П. Педагогика: 100 вопросов - 100 ответов: учеб. пособие для вузов. М.: ВЛАДОС-Пресс, 2004. 365 с.

6. Сунь Юй. Учет когнитивно-психологических характеристик китайских учащихся при обучении русской грамматике // Самарский научный вестник. 2020. №1 (30). С. 283-288.

7. Хуторской А.В. Методика личностно-ориентированного обучения. Как обучать всех по-разному?: Пос. для учителя. М.: Изд. ВЛАДОС-ПРЕСС, 2005. 383 с.

(c) Сунь Юй (st059610@student.spbu.ru).

Журнал «Современная наука: актуальные проблемы теории и практики» 